\section{DIVERSITY OF BUTTERFLIES (LEPIDOPTERA: Papilionoidea AND Hesperoidea) Of Dachigam NATIONAL PARK, JAMMU AND KASHMIR, INDIA}

\section{Aijaz Ahmad Qureshi ${ }^{1}$, R.C. Bhagat ${ }^{2}$ \& Deen Mohd Bhat $^{3}$}

1,2 P.G. Department of Zoology, University of Kashmir, Srinagar, Jammu \& Kashmir, India

${ }^{3}$ Department of Zoology, Government Degree College, Ganderbal, Jammu \& Kashmir 191201, India

Present address: ${ }^{1}$ Islamic University of Science and Technology, Awantipora, Jammu \& Kashmir, India; ${ }^{2}$ P.O.BOX No.1250,

G.P.O, Residency Road, Srinagar, Jammu \& Kashmir 190001, India ${ }^{1}$ draijazphd@gmail.com (corresponding author), ${ }^{2}$ bhagatrc@yahoo.com, ${ }^{3}$ din_ento@yahoo.co.in

Being the main destination for wildlife linked tourism in the Kashmir Valley, Dachigam National Park has attained world-wide fame for its rich faunal and floral wealth. The National Park is situated $18 \mathrm{~km}$ northeast of Srinagar. It covers an area of $141 \mathrm{~km}^{2}$ and is roughly $22.5 \mathrm{~km}$ long, $8 \mathrm{~km}$ wide and an altitude range of 1,700 $>4,000 \mathrm{~m}$. The National Park is divided into lower and upper Dachigam areas and is enclosed between a fold of the Zanskar range, which forms the northwest branch of the central Himalaya (Fig. 1). At its base lies the Harwan Reservoir and New Theed Village, while the surrounding mountain range is topped by Mahadev Peak. Dachigam is famous for the Kashmir Stag or "Hangul" (Cervus elaphus hanglu). The National Park also acts as a protected home for other floral and faunal elements, viz., Himalayan Brown Bear, Himalayan Black Bear, Musk Deer, Leopard, Hyena, birds (150 species), vascular plants (661 species) etc. (Dar et al. 2002).

No survey or study has so far been undertaken on the butterflies of Dachigam National Park. Earlier workers who have contributed to the knowledge of butterfly fauna of Kashmir Valley like Bingham-(1905, 1907),

Evans (1932), Thomas-Glover (1936), Home (1938), Das et al. (1964), Das \& Verma(1965), Talbot (1939, 1947), Wynter-Blyth (1957) and Jamdar (1992)-have not mentioned any reports of

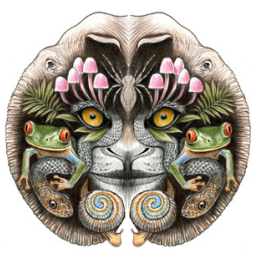

ISSN

Online 0974-7907 Print 0974-7893

\section{OPEN ACCESS}

butterflies from Dachigam area. Among them, Home (1938) reported seven species of butterflies from Nishatbagh, a famous tourist spot close to the national park. Also, most of the surveys/studies conducted in the park till date, have been confined to large animals like Hangul, Leopard, Wild Boar and plants (Holloway 1970; Kurt 1978; Inayatullah 1982; Mansoor 1989; Bhat et al. 2009; Charoo et al. 2009; Qureshi et al. 2009; Shah et al. 2009a,b, 2011). Keeping in view the significance of the national park, the authors made a preliminary survey of its butterfly fauna.

Materials and Methods: The butterflies were surveyed during the period April-June and SeptemberOctober 2004, May-July and October 2005, JuneAugust 2006 and May-July 2007. Adult butterflies were collected by net and identified in the field and in a few cases were collected. For identification, the works of Evans (1932), Wynter-Blyth (1957), Haribal (1992), Feltwell (2001), Kunte (2006) and Pajni et al. (2006) were followed. For common names of butterflies WynterBlyth (1957) and Varshney (1983) were followed.

Observations: In the present field study, 27 species of butterflies distributed in 24 genera and five families were reported (Table 1). The families include Hesperiidae, Papilionidae (one genus, one species each), Lycaenidae (three genera, three species), Pieridae (five genera, seven species) and Nymphalidae (14 genera,

DOI: http://dx.doi.org/10.11609/JoTT.o2886.5389-92 | ZooBank: urn:Isid:zoobank.org:pub:845739D5-3266-4F0E-8229-CB68203AC06F

Editor: Peter Smetacek, Butterfly Research Centre, Bhimtal, India.

Date of publication: 26 January 2014 (online \& print)

Manuscript details: Ms \# 02886 | Received 24 July 2011 | Final received 25 December 2013 | Finally accepted 03 January 2014

Citation: Qureshi, A.A., R.C. Bhagat \& D.M. Bhat (2014). Diversity of butterflies (Lepidoptera: Papilionoidea and Hesperoidea) of Dachigam National Park, Jammu and Kashmir, India. Journal of Threatened Taxa 6(1): 5389-5392; http://dx.doi.org/10.11609/JoTT.02886.5389-92

Copyright: (c) Qureshi et al. 2014. Creative Commons Attribution 3.0 Unported License. JoTT allows unrestricted use of this article in any medium, reproduction and distribution by providing adequate credit to the authors and the source of publication.

Funding: None.

Competing Interest: The authors declare no competing interests.

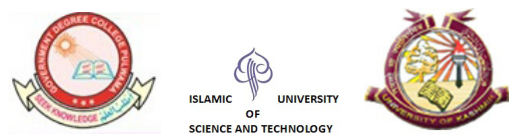

Acknowledgements: The authors are highly thankful to Chief Wildlife Warden-Kashmir, Regional Wildlife Warden-Kashmir and staff at Dachigam National Park for allowing us to conduct this study. 


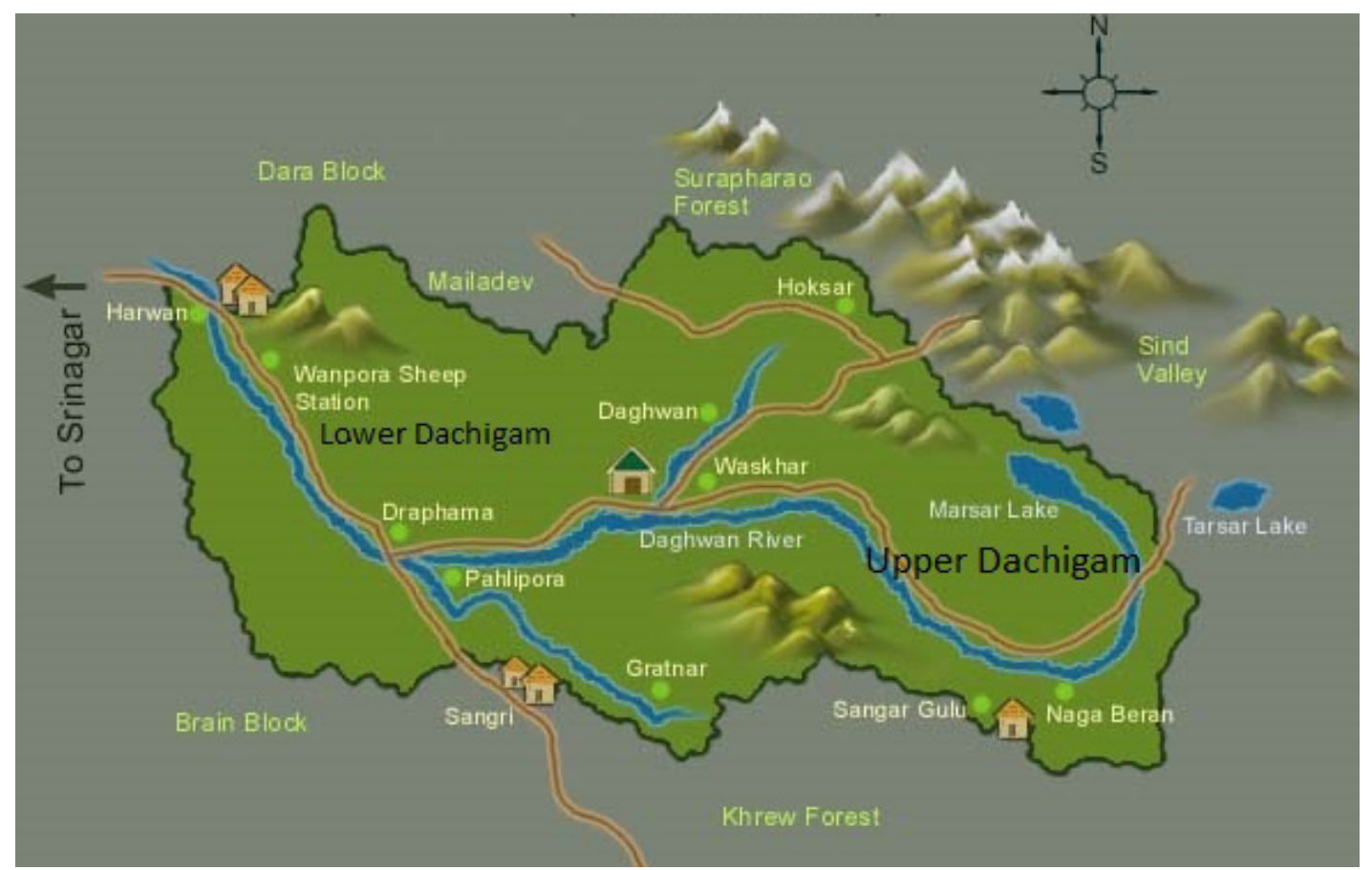

Figure 1. Map of Dachigam National Park

15 species). Nymphalidae was found to be the most dominant followed by Pieridae, Lycaenidae, Hesperiidae and Papilionidae. It was found that the butterflies of all the families except Hesperiidae were mostly active from April to August. However, the family Hesperiidae was active from June to October. Although a total of at least 35 species were seen in the park only 27 were identified, and the rest (which might roughly include three lycaenids, five nymphalids, one papilionid and three pierids) could not be identified. Libythea lepita occurred in the hundreds during the month of April and May 2006. However, such numbers were not observed in other months or years.

Most butterfly species were seen visiting flowers of Tagetes patula (Asteraceae). Two nymphalids namely Junonia orithya (Linnaeus) (Blue Pansy) and Neptis sappho Pallas (Pallas' Sailor) are new records and are reported for the first time from Kashmir Valley. The distribution and abundance of most families except Hesperiidae was during the months of May, June and July. Hesperiidae was abundant during September. Aglais cashmirensis, Vanessa cardui, Colias fieldi, Pieris brassicae and Pontia daplidice were the commonest butterflies throughout the study period.

Aglais cashmirensis, Argynnis childreni, Hypolimnas misippus, Junonia orithya, Kaniska canace, Libythea lepita, Neptis sappho, Aricia agestis, Lampides boeticus, Lycaena phlaeas, Papilio machaon, Pelopidas mathias,
Aporia soracta, Colias fieldi, Gonepteryx rhamni, Pieris brassicae, P. canidia and Pontia daplidice were found mud puddling on warm days. Species like Argynnis hyperbius, Argynnis childreni, Callerebia nirmala, Danaus chrysippus, Hypolimnas misippus, Kaniska canace, Neptis sappho, Pararge eversmanni cashmirensis, Vanessa indica, Papilio machaon, Aporia soracta, Gonepteryx rhamni and Colias erate were not frequently observed as compared to other reported species. Since the present preliminary study was mostly confined to the lower areas of the National Park, it was not possible to fully explore the butterfly wealth of the park.

Conclusion: The present study is the first effort in exploring the butterfly wealth of Dachigam National Park. The permission and entry process for conducting research needs to be reviewed and simplified. While processing extension/renewal of the permission, a lot of time gets wasted which ultimately affects the outcome of such surveys.

\section{References}

Bhat, B.A., G.M. Shah, U. Jan, F.A. Ahanger \& M.F. Fazili (2009). Observations on rutting behaviour of Hangul Deer Cervus elaphus hanglu (Cetartiodactyla: Cervidae) in Dachigam National Park, Kashmir, India. Journal of Threatened Taxa 1(6): 355-375.

Bingham, C.T. (1905). The Fauna of British India including Ceylon and Burma - Butterflies Vol. I. Taylor and Francis Ltd. London, 511pp.

Bingham, C.T. (1907). The Fauna of British India including Ceylon and Burma - Butterflies Vol. II. Taylor and Francis Ltd. London, 480pp.

Charoo, S.A., L.K. Sharma \& S. Sathyakumar (2009). Asiatic Black 
Table 1. Butterflies of Dachigam National Park.

\begin{tabular}{|c|c|c|c|}
\hline & Scientific Name & Common Name & $\begin{array}{l}\text { Flight } \\
\text { Period }\end{array}$ \\
\hline & Family: Hesperiidae & & \\
\hline \multirow[t]{2}{*}{1} & \begin{tabular}{|l} 
Pelopidas mathias \\
(Fabricius) \\
\end{tabular} & Small Branded Swift & $\begin{array}{l}\text { June to } \\
\text { October }\end{array}$ \\
\hline & Family: Lycaenidae & & \\
\hline 2 & $\begin{array}{l}\text { Aricia agestis } \\
\text { (Denis \& Schiffermuller) } \\
\end{array}$ & Orange-Bordered Argus & $\begin{array}{l}\text { April to } \\
\text { October }\end{array}$ \\
\hline 3 & Lampides boeticus Linnaeus & Pea Blue & $\begin{array}{l}\text { May to } \\
\text { September }\end{array}$ \\
\hline \multirow[t]{2}{*}{4} & $\begin{array}{l}\text { Lycaena phlaeas } \\
\text { (Linnaeus) }\end{array}$ & Common Copper & $\begin{array}{l}\text { May to } \\
\text { September }\end{array}$ \\
\hline & Family: Nymphalidae & & \\
\hline 5 & $\begin{array}{l}\text { Aglais cashmirensis } \\
\text { (Kollar) }\end{array}$ & Indian Tortoiseshell & $\begin{array}{l}\text { March to } \\
\text { November }\end{array}$ \\
\hline 6 & $\begin{array}{l}\text { Argynnis hyperbius } \\
\text { (Johanssen) }\end{array}$ & Indian Fritillary & $\begin{array}{l}\text { May to } \\
\text { October }\end{array}$ \\
\hline 7 & Argynnis childreni (Gray) & Large Silverstripe & $\begin{array}{l}\text { May to } \\
\text { October }\end{array}$ \\
\hline 8 & Callerebianirmala(Moore) & Common Argus & $\begin{array}{l}\text { April to } \\
\text { September }\end{array}$ \\
\hline 9 & Danaus chrysippus Linnaeus & Plain Tiger & $\begin{array}{l}\text { May to } \\
\text { August } \\
\end{array}$ \\
\hline 10 & $\begin{array}{l}\text { Hypolimnas misippus } \\
\text { (Linnaeus) }\end{array}$ & DanaidEggfly & $\begin{array}{l}\text { May to } \\
\text { October }\end{array}$ \\
\hline 11 & $\begin{array}{l}\text { Issoria lathonia } \\
\text { (Linnaeus) }\end{array}$ & $\begin{array}{l}\text { Queen of } \\
\text { Spain Fritillary }\end{array}$ & $\begin{array}{l}\text { May to } \\
\text { September }\end{array}$ \\
\hline 12 & $\begin{array}{l}\text { Junonia iphita } \\
\text { (Crammer) }\end{array}$ & Chocolate Pansy & $\begin{array}{l}\text { May to } \\
\text { September }\end{array}$ \\
\hline 13 & $\begin{array}{l}\text { Junonia orithya } \\
\text { (Linnaeus) }\end{array}$ & Blue Pansy & \begin{tabular}{|l|} 
April to \\
October
\end{tabular} \\
\hline 14 & $\begin{array}{l}\text { Kaniska canace } \\
\text { (Linnaeus) }\end{array}$ & Blue Admiral & $\begin{array}{l}\text { May to } \\
\text { September }\end{array}$ \\
\hline 15 & $\begin{array}{l}\text { Libythea lepita } \\
\text { Moore }\end{array}$ & Common Beak & $\begin{array}{l}\text { April to } \\
\text { September }\end{array}$ \\
\hline 16 & Neptis sappho Pallas & Pallas' Sailer & $\begin{array}{l}\text { May to } \\
\text { September }\end{array}$ \\
\hline 17 & $\begin{array}{l}\text { Pararge } \\
\text { everesmanni cashmirensis } \\
\text { Eversmann }\end{array}$ & Yellow Wall & $\begin{array}{l}\text { May to } \\
\text { August }\end{array}$ \\
\hline 18 & \begin{tabular}{|l} 
Vanessa cardui \\
(Linnaeus) \\
\end{tabular} & Painted Lady & $\begin{array}{l}\text { April to } \\
\text { November }\end{array}$ \\
\hline \multirow[t]{2}{*}{19} & $\begin{array}{l}\text { Vanessa indica } \\
\text { (Herbst) }\end{array}$ & Indian Red Admiral & $\begin{array}{l}\text { May to } \\
\text { September }\end{array}$ \\
\hline & Family: Papilionidae & & \\
\hline \multirow[t]{2}{*}{20} & $\begin{array}{l}\text { Papilio machaon } \\
\text { Menetries }\end{array}$ & $\begin{array}{l}\text { Common Yellow } \\
\text { Swallowtail }\end{array}$ & $\begin{array}{l}\text { April to } \\
\text { September }\end{array}$ \\
\hline & Family: Pieridae & & \\
\hline 21 & Aporia soracta Moore & Himalayan Blackvein & $\begin{array}{l}\text { April to } \\
\text { May }\end{array}$ \\
\hline 22 & Colias fieldi Menetries & Dark Clouded Yellow & $\begin{array}{l}\text { April to } \\
\text { November }\end{array}$ \\
\hline 23 & Colias erate Esper & Pale Clouded Yellow & $\begin{array}{l}\text { April to } \\
\text { November }\end{array}$ \\
\hline 24 & $\begin{array}{l}\text { Gonepteryxr hamni } \\
\text { (Linnaeus) }\end{array}$ & Common Brimstone & $\begin{array}{l}\text { April to } \\
\text { November }\end{array}$ \\
\hline 25 & Pieris brassicae (Linnaeus) & Large Cabbage White & $\begin{array}{l}\text { February to } \\
\text { November }\end{array}$ \\
\hline 26 & Pieris canidia (Sparrman) & Indian Cabbage White & $\begin{array}{l}\text { May to } \\
\text { October }\end{array}$ \\
\hline 27 & Pontia daplidice (Linnaeus) & Bath White & $\begin{array}{l}\text { April to } \\
\text { November }\end{array}$ \\
\hline
\end{tabular}

Bear - Human Conflicts around Dachigam National Park, Kashmir. Technical Report. Wildlife Institute of India, Dehradun, 51pp.

Dar, G.A., R.C. Bhagat \& M.A. Khan (2002). Biodiversity of the Kashmir Himalaya. Valley Book House, Srinagar, India, 399pp.

Das, S.M. \& K.D. Verma (1965). The Insects of Kashmir (a special entomo-fauna). Kashmir Science 2(1-2): 142-146.

Das, S.M., Y.R. Malhotra \& P.L. Duda (1964). The Palaearctic elements in the fauna of Kashmir region. Kashmir Science 1(1-2): 100-111.

Evans, B.W.H (1932). The Identification of Indian Butterflies. Diocesan Press, Madras, India, 454pp.

Feltwell, J. (2001). The Illustrated Encyclopedia of Butterflies. Chartwell Books, New Jersey, USA, 288pp.

Haribal, M. (1992). The Butterflies of Sikkim Himalaya and their Natural History. Sikkim Nature Conservation Foundation (SNCF), Gangtok, Sikkim, 217pp.

Holloway, C.S. (1970). The Hangul in Kashmir: a census. Oryx 10(6): 373-382.

Home, W.M.L. (1938). Some notes on butterflies and big game in Kashmir. Journal of the Bombay Natural History Society 40(1): 4955.

Inayatullah, M. (1982). The project Hangul, pp. 164-173. In: Saharia, V.B. (ed.). Wildlife in India. Natraj Publishers, Dehradun, India.

Jamdar, N. (1992). On the migration of the Large Cabbage White Butterfly Pieris brassicae in Kashmir. Journal of the Bombay Natural History Society 88(2): 297-298.

Kunte, K. (2006). India - A Lifescape, Butterflies of Peninsular India. Universities Press (India) Private Ltd. Hyderabad, India, 254pp.

Kurt, F. (1978). Kashmir deer (Cervus elephus hanglu) in Dachigam. IUCS Publication, New Series.

Mansoor, M. (1989). Extinction of Wild boar (Susscrofta) from Dachigam National Park, Jammu \& Kashmir State. Zoos' Print 4(10): 19-20.

Pajni, H.R., H.S. Rose \& V.K. Walia (2006). Butterflies of North-West India - part 1. Atma Ram \& Sons, Chandigarh, India, 115pp.

Qureshi, Q., N. Shah, A.R. Wadoo, R.Y. Naqqash, M.S. Bacha, N.A. Kitchloo, J.N. Shah, I. Suhail, S. Iqbal, K. Ahmad, I.A. Lone, M. Mansoor, R.A. Zargar, S. Hussain, M.M. Baba, M.M. Parsa, A. R. Latoo \& I. Dewan (2009). Status and distribution of Hangul Cervus elephus hanglu Wagner in Kashmir, India. Journal of the Bombay Natural History Society 106(1): 63-71.

Shah, G.M., U. Jan, B.A. Bhat \& F.A. Ahanger (2011). Causes of decline of critically endangered Hangul Deer in Dachigam National Park, Kashmir (India) - A review. International Journal of Biodiversity and Conservation 3(14): 735-738; http://dx.doi.org/10.5897/ IJBC11.058

Shah, G.M., U. Jan, B.A. Bhat, A. Ahmad \& J. Ahmad (2009). Food habits of the Leopard Panthera pardus in Dachigam National Park, Kashmir, India. Journal of Threatened Taxa 1(3): 184-185; http:// dx.doi.org/10.11609/JoTT.o1833.184-5

Shah, G.M., U. Jan, B.A. Bhat, A. Ahmad \& J. Ahmad (2009a). Diets of Hangul Deer Cervus elaphus hanglu (Cetartiodactyla: Cervidae) in Dachigam National Park, Kashmir, India. Journal of Threatened Taxa 1(7): 398-400; http://dx.doi.org/10.11609/JoTT.02186.398-400

Talbot, G. (1939). The Fauna of British India including Ceylon and Burma - Butterflies. Vol. I. Taylor and Francis Ltd. London, 589pp.

Talbot, G. (1947). The Fauna of British India including Ceylon and Burma - Butterflies vol. II. Taylor and Francis Ltd. London, 506pp.

Thomas-Glover, J.W. (1936). Butterflies and moths from Chinese Turkistan. Journal of the Bombay Natural History Society 39: 756768.

Varshney, R.K. (1983). Index Rhopalocera Indica. Part II. Common Names of Butterflies from India and Neighbouring Countries. Records of the Zoological Survey of India. Occasional paper No. 47, 1-47pp.

Wynter-Blyth, M.A (1957). Butterflies of the Indian Region. The Bombay Natural History Society, Bombay, India, 523pp. 


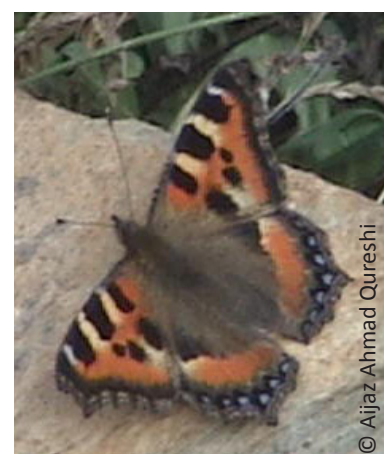

Image 1. Aglais cashmirensis

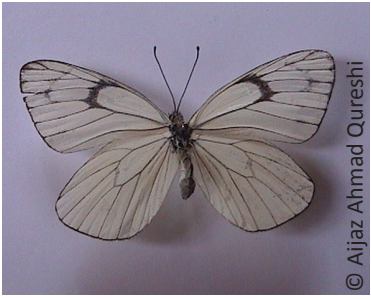

Image 5. Aporia soracta

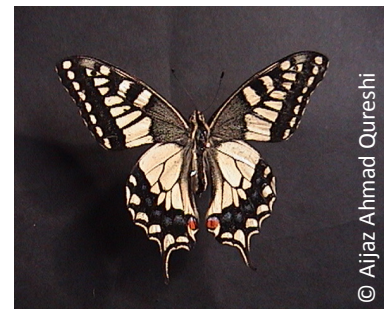

Image 9. Paplio machaon

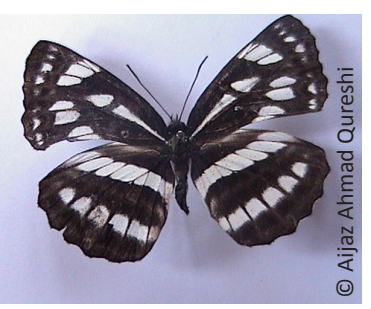

Image 13. Neptis sappho (upperside)

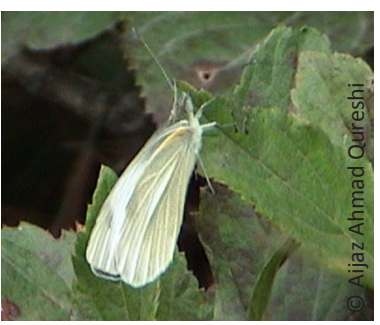

Image 17. Pieris canidia

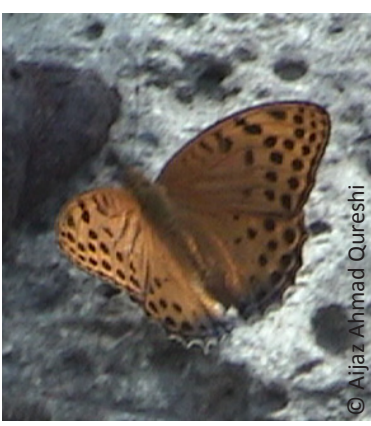

Image 2. Argynnis childreni

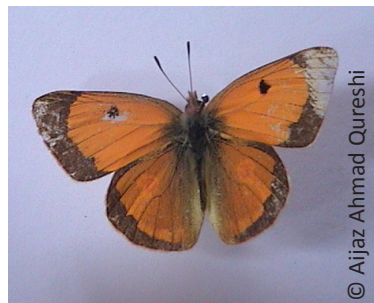

Image 6. Colias fieldi

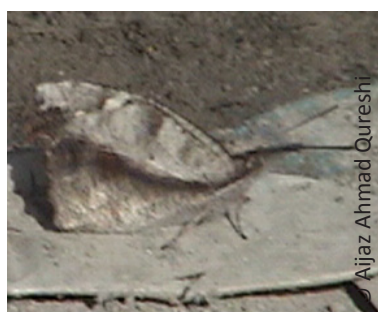

Image 10. Libythea lepita

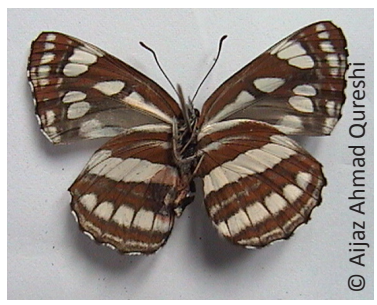

Image 14. Neptis sappho (underside)

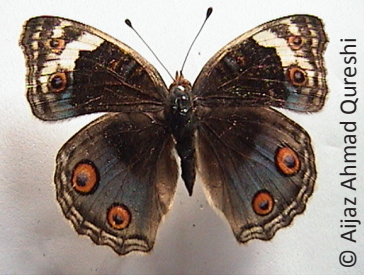

Image 19. Junonia orithya

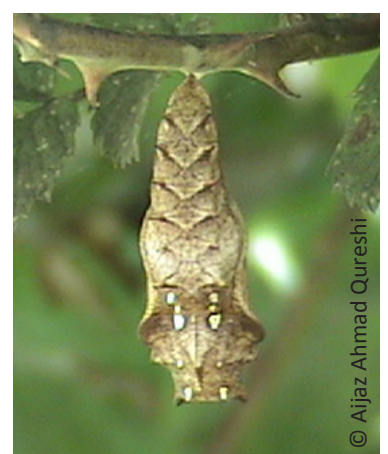

Image 3. Pupa of Argynnis childreni

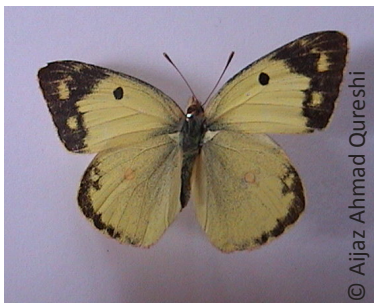

Image 7. Colias erate

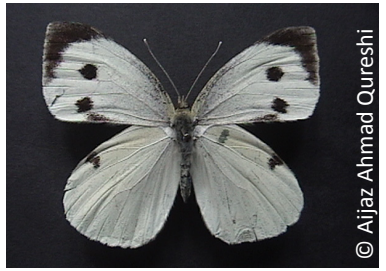

Image 11. Pieris brassicae

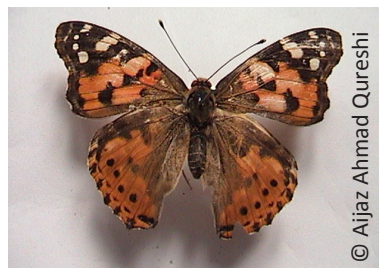

Image 15. Vanessa cardui

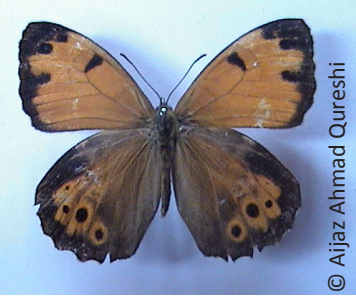

Image 20. Parage eversmanni cashmirensis

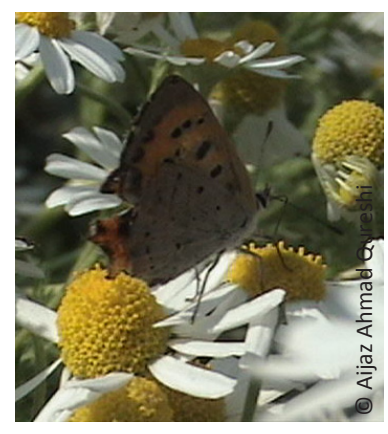

Image 4. Lycaena phlaeas

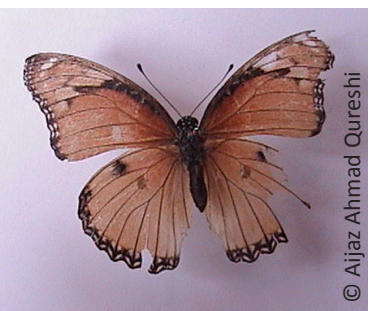

Image 8. Hypolimnas missipus

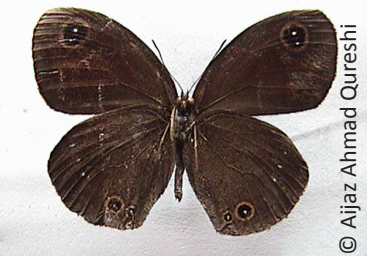

Image 12. Callerebia nirmala

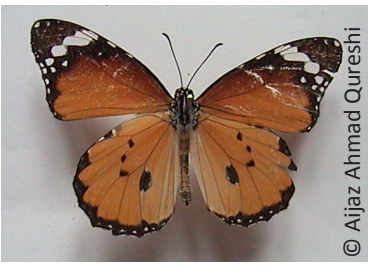

Image 16. Danaus chrysippus

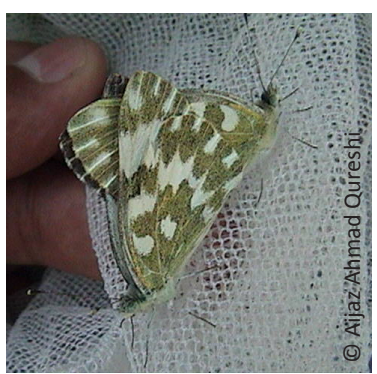

Image 21. Pontia daplidice during mating 